\title{
In Vitro Antibacterial Properties of Ethanol Extract from Salvia Officinalis (L.) Plant Growing Wild in Kosovo
}

\author{
Arben Haziri ${ }^{1}$, Fatmir Faiku ${ }^{1}$, Arben Mehmeti $^{2}$, Kemajl Kurteshi ${ }^{1}$, Imer Haziri ${ }^{2}$, Ibrahim Rudhani ${ }^{3 *}$ \\ ${ }^{1}$ Mathematical and Natural Science Faculty, University of Prishtina, Kosovo \\ ${ }^{2}$ Agricultural and Veterinary Faculty, University of Prishtina, Kosovo \\ ${ }^{3}$ Medicinal Faculty, university of Prishtina, Kosovo
}

Received: January 27, 2018; Published: February 09, 2018

*Corresponding author: Ibrahim Rudhani, Medicinal Faculty, university of Prishtina, 10000 Prishtina, Kosovo; Email: ibrahim.rudhani@uni-pr.edu

\begin{abstract}
In this study the antibacterial efficiency of ethanol extract from Salvia officinalis (L.) growing wild in Kosovo were examined. Ethanol extract was tested against two gram positive bacteria Staphylococus aureus (clinical isolate), Listeria monocytogenes (clinical isolate) and one gram negative bacteria Escherichia coli (clinical isolate). The antibacterial activity was determined by using agar disc diffusion method. The inhibition zone of extract was compared to that of penicillin G. The ethanol extract showed activity in all of the concentrations $1,3 \mathrm{and} 5 \mathrm{mg} /$ $\mathrm{mL}$ towards E. coli, S. aureus and L. Monocytogenes. Ethanol extract of the plant with concentration $5 \mathrm{mg} / \mathrm{mL}$ showed a stronger antibacterial activity towards bacteria $S$. aureus with inhibition zone of $9 \mathrm{~mm}$. The antibacterial activity of the $S$. officinalis (L.) was due to the presence of various secondary metabolites such as phenols and flavonoids. Hence, this plant can be used to discover bioactive natural products that may serve as leads in the development of new pharmaceuticals.
\end{abstract}

Keywords: Salvia officinalis (L.); Antibacterial activity; Agar disk diffusion method; Ethanol extract

\section{Introduction}

The heterogeneous relief of Kosovo with the diversity of soil types, are responsible for the heterogeneousness of the Kosovo flora [1]. The secondary metabolism of the plants which are responsible for the biological activities are terpenes, phenolics and nitrogencontaining compounds. The antibiotics drugs obtained from plants are of greater interest in comparison to synthetic ones. The use of natural antibiotics from plants does not induce the secondary health effects (abdominal pain, diarrhea, cramping, headache, nausea and vomiting etc). Plant products may be used as antibiotic alternatives and do not cause resistance in bacteria [2].

The genus Salvia, commonly called sage, is the largest member of Lamiaceae or mint family containing over 900 species throughout the world [3]. Salvia officinalis L., probably the most known species of the Salvia genus and commonly known as garden or red sage, is a perennial hardy sub-shrub native to Mediterranean regions and is one of the most popular medicinal and culinary herbs used in the world [4,5]. Sage water extracts has been traditionally used for the treatment of digestive and circulation disturbances, bronchitis, cough, asthma, angina, mouth and throat inflammations, depression, excessive sweating, skin diseases, and many other diseases. In addition, they possess a number of biological activities including antiseptic, antibacterial, antioxidant, antiviral and antimycobacterial activities [6-19]. The antibacterial effect of the ethanol extracts, obtained from the medicinal plants, has been studied by a number of researchers in different parts of the world. Our research group was interested to analyze the biological activities of different medicinal plants extracts growing in different region of Kosovo. The aim of this study was to investigate the antibacterial activity of ethanol extracts of Salvia officinalis L. growing wild in Kosovo.

\section{Experimental \\ Plant Material}

The S. officinalis L. plant was collected in 2015 in Kosovo. Voucher specimens were deposited in the herbarium of the Department of Plant Protection, University of Prishtina. The aereal part of this medicinal plant were air dried at room temperature within three weeks. 


\section{Preparation of Plant Organic Extracts}

The aerial part of $S$. officinalis (L.) was air-dried and then milled with a mixer. A piece of finely powdered material $(200 \mathrm{~g}$ ) was extracted with $70 \%$ ethanol $\left(\mathrm{CH}_{3} \mathrm{CH}_{2} \mathrm{OH}, 4 \mathrm{~L}\right)$ during a $24 \mathrm{~h}$ period (three times). After removing the solvent by vacuum rotary evaporator (EYELA N-1000, Japan) the crud product was dissolved in DMSO to prepare the solution with the concentration 1, 3 and $5 \mathrm{mg} / \mathrm{mL}$. The solutions are used in subsequent experiments for testing their antibacterial. Etanol (analytical grade) for extraction were obtained from Sigma-Aldrich.

\section{Antibacterial Activity}

The antibacterial activity of the S. officinalis (L.) extracts obtained by using the ethanol organic solvents are determined applying the Kirby-Bayer [19] method or disk method (d = $5.5 \mathrm{~mm}$, maximum capacity $10 \mathrm{mg}$ ). S. officinalis (L.) extracts were tested in an in vitro experiment against bacterial strains; $S$. aureus (clinical isolate with code 3319), L. monocytogenes (clinical isolate with code 2653) and E. coli (clinical isolate with code 2813). For the research we used three diferent concentration of ethanol extract, 1, 3 and $5 \mathrm{mg} / \mathrm{mL}$ in DMSO as solvent and then placed in a Petri dishes $(\mathrm{d}=15 \mathrm{~cm})$. The disks were incubated at $370 \mathrm{C}$ for $48 \mathrm{~h}$; the control was also maintained with penicillin G dissolved in DMSO in a similar manner.

\section{Results and Discussion}

During the antibacterial activity, we have tested the extracts from the plant $S$. officinalis (L.) against bacteria: S. aureus (positive Gram bacteria), L. monocytogenes (positive Gram bacteria) and E. coli (negative Gram bacteria-clinical isolate). Antibacterial activity of the ethanol extracts were compared with Penicillin G- a substance, which can be found in the market and have been used with concentration 1,3 and $5 \mathrm{mg} / \mathrm{mL}$ as a standard. The comparison is done in accordance to the measurements of the diameter of the inhibition zone that is formed. These results are shown in Table 1.

Extracts of ethanol (1, 3 and $5 \mathrm{mg} / \mathrm{mL}$ ) shows antibacterial activities against $S$. aureus, L. monocytogenes and E. coli (Table 1 and Figure 1). The extracts of ethanol resulted in a lower activity than the penicillin $\mathrm{G}$ of the same concentration against $E$. coli (Table 1 and Figure 1). The extract of ethanol with concentration of $3 \mathrm{mg} /$ $\mathrm{mL}$ and $5 \mathrm{mg} / \mathrm{mL}$ has higher inhibition zone $(7 \mathrm{~mm})$ as the standard (6 $\mathrm{mm}$ ) against L. monocytogenese. The extract with concentration $1 \mathrm{mg} / \mathrm{mL}$ resulted in lower activity than the penicillin G with the same concentration against L. monocytogenese (Table 1 and Figure 1). The extracts of ethanol with concentration of $5 \mathrm{mg} / \mathrm{mL}$ have the same inhibition zone as the standard (inhibition zone $6 \mathrm{~mm}$ ) against $S$. aureus (Table 1 and Figure 1).

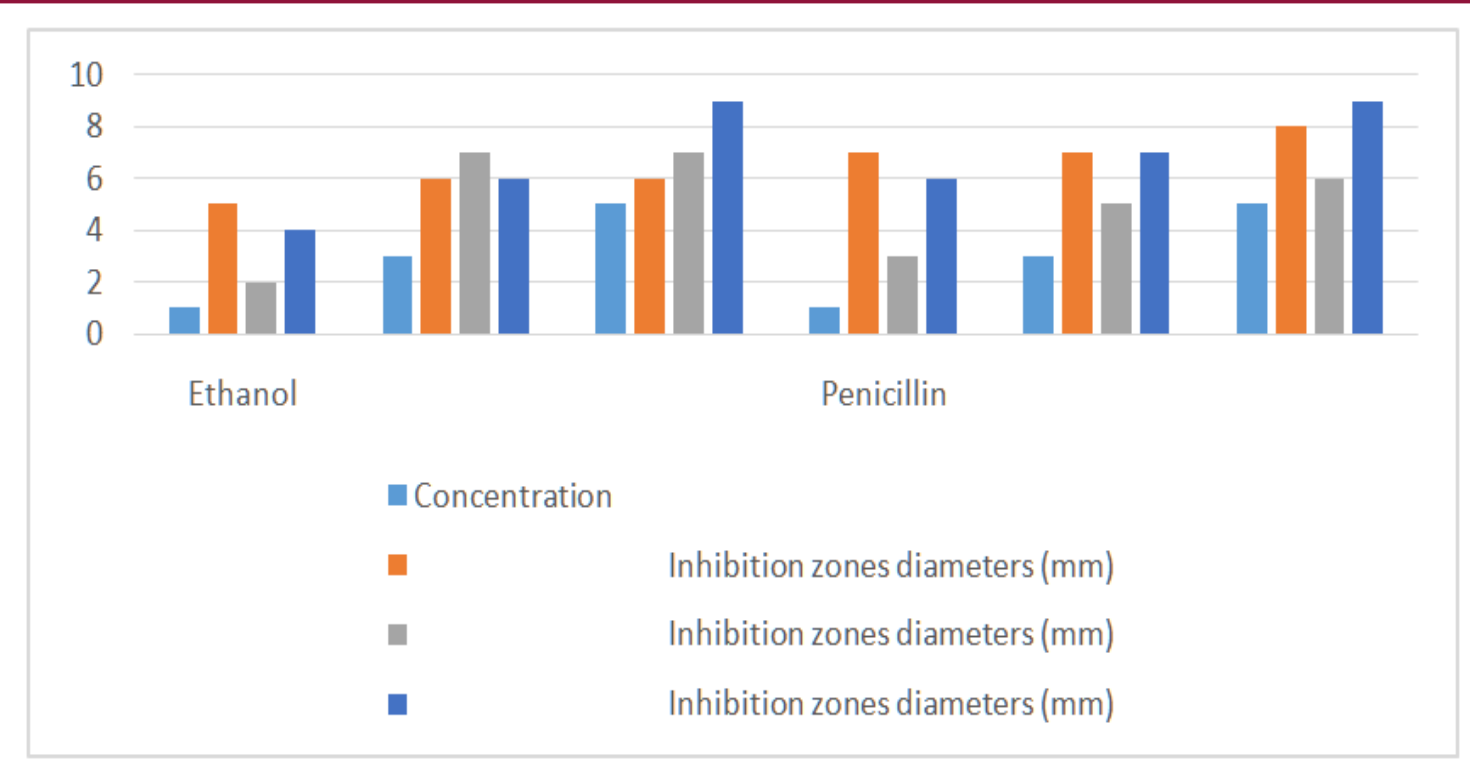

Figure 1: Antibacterial activity of ethanol extracts from S. officinalis (L.).

Table 1: Inhibition zones diameters of S. officinalis (L.) ethanol extracts.

\begin{tabular}{|c|c|c|c|c|}
\hline \multirow{3}{*}{ Extracts } & Concentration & \multicolumn{3}{|c|}{ Inhibition zones diameters (mm) } \\
\cline { 2 - 5 } & (mg/ml) & E. coli (c. i.) & L. monocytogenes(c. i.) & S. aureus(c. i.) \\
\hline \multirow{3}{*}{ Ethanol } & 1 & 5 & 2 & 4 \\
\cline { 2 - 5 } & 3 & 6 & 7 & 9 \\
\cline { 2 - 5 } & 5 & 6 & 3 & 6 \\
\hline \multirow{2}{*}{ Penicillin } & 1 & 7 & 5 & 7 \\
\cline { 2 - 5 } & 3 & 7 & 6 & 9 \\
\hline
\end{tabular}




\section{Conclusion}

S. officinalis (L.) is a medicinal plant used in folk medicine for different health illnes. The aim of this research was to analyse the antibacterial activities of ethanol extracts from S. officinalis (L.) plant growing wild in Kosovo. Based on the results, the three concentrations of the extract showed a very good activity by inhibiting the growth of all the tested bacteria. Ethanol extract of the plant with concentration $5 \mathrm{mg} / \mathrm{mL}$ showed a stronger antibacterial activity towards bacteria $S$. aureus, E. coli and L.monocytogenes (clinical isolate). Extract with concentration $5 \mathrm{mg} / \mathrm{mL}$ showed a higher antibacterial activity against bacteria L.monocytogenes. Results obtained from ethanol extracts of $S$. officinalis(L.) for antibacterial activity are logical, based on numerous of studies where these extracts were analyzed in the content of flavonoids, phenols, terpenes, alkaloids, etc., and these components are responsible for the biological activity.

\section{References}

1. Mehmeti A, Sherifi E, Demaj A (2007) Medical Herbs (European Agency for Reconstruction), $1^{\text {st }}$ edition, Prishtine, Kosovo 46.

2. Gibbons S (2005) Plants as a source of bacterial resistance modulators and anti-infective agents Phytochemistry 4(1): 63-78.

3. Hamidpour S, Hamidpour M, Shahlari M (2013) Sage: The functional novel natural medicine for preventing and curing chronic illnesses. International Journal of Case Reports and Images 4: 671-677.

4. Grzegorczy KI, Królicka A, Wysokińska H (2006) Establishment of Salvia officinalis L. hairy root cultures for the production of rosmarinic acid. Z Naturforsch C 61(5-6): 351-356.

5. Qnais EY, Abu-Dieyeh M, Abdulla FA, Abdalla SS (2010) The antinociceptive and antiinflammatory effects of Salvia officinalis leaf aqueous and butanol extracts. Pharm Biol 48(10): 1149-1156.

6. Hamidpour R, Hamidpour S, Shahlari M (2014) Chemistry, Pharmacology, and Medicinal Property of Sage (Salvia) to Prevent and Cure Illnesses such as Obesity, Diabetes, Depression, Dementia, Lupus, Autism, Heart Disease, and Cancer. J Tradit Complement Med 4(2): 82-88.
7. Yang Z, Kitano Y, Chiba K, Shibata N, Kurokawa H et al. (2001) Synthesis of variously oxidized abietanediterpenes and their antibacterial activities against MRSA and VRE. Bioorg Med Chem 9(2): 347-356.

8. Abd-Elmageed MM, Hussein BA (2008) Cytotoxicity and antimicrobial activity of Salvia officinalis L. Flowers. Sudan JMS 3(2): 127-130.

9. Lima CF, Andrade PB, Seabra RM, Fernandes-Ferreira M, Pereira-Wilson C (2005) The drinking of a Salvia officinalis infusion improves liver antioxidant status in mice and rats J Ethnopharmacol 97(2): 383-389.

10. Baricevic D, Sosa S, Della LR, Tubaro A, Simonovska B, et al. (2001) Topical antiinflammatory activity of Salvia officinalis L. leaves: The relevance of ursolic acid. J Ethnopharmacol 75(2-3): 125-132.

11. Akkol EK, Goger F, Kosar M, Baser KHC (2008) Phenolic composition and biological activities of Salvia halophila and Salvia virgata from Turkey. Food Chem 108(3): 942-949.

12. Çadirci E, Süleyman H, Gürbüz P, Kuruüzüm UA, Güvenalp Z et al. (2012) Antiinflammatory effects of different extracts from three Salvia species. Turk J Biol 36: 59-64.

13. Tada M, Okuna K, Chiba K, Ohnishia E, Yoshiia T (1994) Antiviral diterpenes from Salvia officinalis Phytochemistry 35(2): 539-541.

14. Smidling D, Mitic-Culafic D, Vukovic-Gacic B, Simic D, Knezevic-Vukcevic J (2008) Evaluation of antiviral activity of fractionated extracts of Sage Salvia officinalis L (Lamiaceae). Arch BiolSci Belgrade 60(3): 421-429.

15. Fiore G, Nencini C, Cavallo F, Capasso A, Bader A, et al. (2006) In vitro antiproliferative effect of six Salvia species on human tumor cell lines. Phytother Res 20(8): 701-703.

16. Ryu SY, Lee CO, Choi SU (1997) In vitro cytotoxicity of tanshinones from Salvia miltiorrhiza Planta Med 63(4): 339-342.

17. ZareShahneh F, Valiyari S, Baradaran B, Abdolalizadeh J, Bandehagh A, et al. (2013) Inhibitory and cytotoxic activities of salvia officinalis L. Extract on human lymphoma and leukemia cells by induction of apoptosis. Adv Pharm Bull 3(1): 51-55.

18. Aş̧un T, Bașer KH., Tümen G, Kürkçüoğlu M (2010) Characterization of essential oils of some Salvia species and their antimycobacterial activities). Turk J Biol 34(1): 89-95.

19. Barry L (1991) Procedure and Theoretical Consideration for Testing Antimicrobial Agents in Agar Media. $5^{\text {th }}$ edition, William Wilkins, Baltimore, Maryland 8-10.
This work is licensed under Creative Commons Attribution 4.0 License

Submission Link: http://biomedres.us/submit-manuscript.php

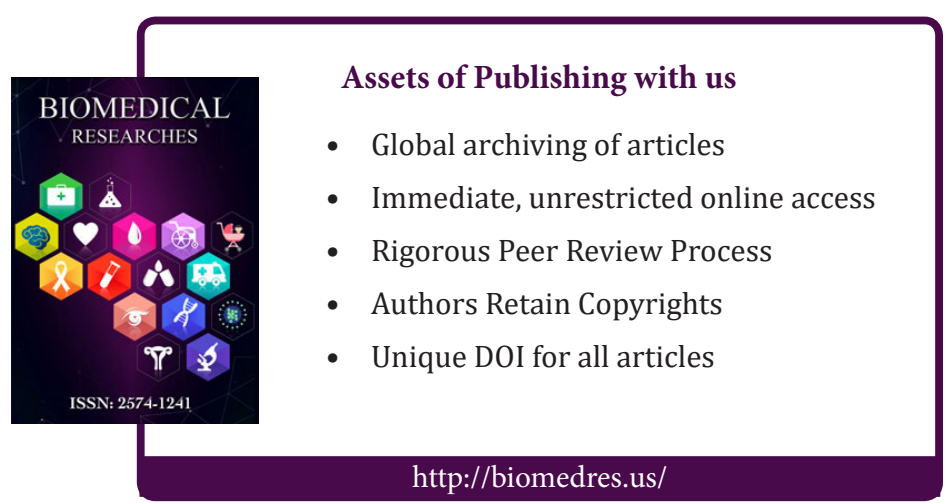

